indeed, the few experiments of the French observers, and of Gilbert Child and Bastian in this country are the only ones at present made.

The reason is obvious, the conditions of the cxperiment and observation required are so difficult that we have not yet mastered them. They are first, to ensure all the favouring circumstances in the laboratory experiment which naturial stations afford, and, of course, to ensure them it is necessary to know or have some idea (which biologists have not) as to what they may be; second, to exclude simultaneously all living matter; third, to make the observations throughout with the greatest minuteness which the microscope permits-a necessary condition, on account of the possible smallness of particles of living matter. When we have had experiments performed in this way with a vast variety in the first-named set of conditions, so as to obtain and study the action of various natural circumstances which might possibly be present in the de novo origination of living from mineral matter-then we may speak of evidence on the question. As it is, we have but a very incomplete and discordant series of observations on one class of conditions in which there is a presumption of spentaneous generation (the case of Bacterium), and which have been selected for experiments on account of a supposed facility for isolation, without interference with the conditions, but of which very little is understood at all. I venture to submit that this single case, in which there has been some little investigation with, be it granted, negative result, so far from warranting the enunciation of a dogma, which is declared to be as sure as a great law expressing the concurrence of almost infinitely numerous, varied, and reiterated observations, does rot even justify an opinion; it has no possible bearing upon the source of the minute protoplasmic particles which the microscopist finds abundantly in sea-water, nor upon the origin of the atmospheric germs which are so largely invoked by some persons. It leaves us necessarily to a priori considerations in regard to the origin of life on the earth, and until direct researches are made, the hypothesis developed by a priori argument must have far more claim on the adhesion of an unbiassed mind, than a pseudo-law, though the latter bear an authority so great in some departments of science as is that of Sir William Thomson.

\section{E. RAY LANKESTER}

\section{RECENT HRENCH ZOOLOGICAL DISCOVERIES}

TWO naturalists, who have been more than usually successful in their investigations of the faunas of distant and little-known countries, have recently returned to France, and are now engaged in working out the results of their arduous expeditions. These are M. le Père Armand David, and M. Alfred Grandidier.

$M$. le Père Armand David is a missionary priest of the Order of Lazarists, who was for many years resident at Pekin. Here he devoted much time and attention to the fauna of the surrounding country, which was at that period little known, and entering into communication with the authorities of the Jardin des Plantes of Paris, supplied that establishment with many interesting novelties. Anongst these one of the most remarkable was a new deer with very peculiar horns and a long tail, which was named by M. Alphonse Milne-Edwards Elaphurus davidianus, after its indefatigable discoverer. But about two years ago Father David moved the seat of his investigations into still more promising quarters. It was, we believe, the magnificent new species of Pheasants transmitted by Bishop Chauveau from Ta-tsien-leou-a town in Western Szechuen upon the frontiers of Tibet-that first called his attention to the probable richness of this district in other departments of zoology. Nor have his expectations been in any way disappointed. The collections of Mammals, Birds, and Reptiles, obtained by Father
David during the recent exploration of Mopin, as this portion of the Celestial Empire is termed by the French writers, have of late years seldom been equalled in any part of the world for extent or variety. The fauna of these mountains seems to be a sort of pendant to that of the Himalayas, which, some years ago, was so successfully investigated by $\mathrm{Mr}$. Hodgson. The singular AElumus or Wah, of Nepal, is replaced by a larger and even stranger form, the \& I turopus of M. Milne-Edwards, a large bear-like mammal, quite distinct from anything previously known. A long-haired monkey inhabits the pine forests, remarkable for the development of its nose, which the same naturalist has proposed to name kininopithecus. The Takin of the Mishnees of Upper Assam (Budorcas taxicolor) is represented by a second species of this most singu'ar genus of Ruminants. A new form of Cervidæe is remarkable for its small horns and well-developed canines; and there are a host of interesting novelties belonging to the insectivorous and rodent orders in Père David's series. In birds, M. Jules Verreaux, to whom the working out of this part of M. Davia's collections has been assigned, has already discriminated upwards of thirty new species. Amongst these many belong to the remarkable genera discovered by $\mathrm{Mr}$. Hodgson in the hill-forests of Nepaul, and hitherto unknown to occur elsewhere. Perhaps the most noteworthy of them is a small Passerine form allied to Paradoxornis, which has only three toes, a phenomenon hitherto unknown, in that typical order of birds. The Reptiles and Batrachians obtained by Father David in Moupin are also said to contain many novelties. Since the lamented death of Prof. Duméril, their investigation has, we believe, been undertaken by Prof. Blanchard, who has within these few last days brought before the French Academy a notice of one of the most extraordinary animals of the latter group. This is no other than a gigantic aquatic Salamander allied to, but distinct from, the now well-known Sieboldia maxima, of Japan. The discovery of this form of life in continental Asia is a fact of the highest significance as regards geographical distribution, as it was previously believed to be in the present epoch confined to the Japanese Islands, though remains of a closely allied animal (Andrias scheuchzcri) are found in the tertiary freshwater deposits of Central Europe.

We have mentioned only a few of the principal dis. coveries of M. David, but enough has been said to show the importance of the additions he has made to zoological science, and to heighten the interest attaching to thc. complete investigation of the fauna of the Chinese frontier of Tibet, which this distinguished naturalist has thus inaugurated.

While Father David has been labouring among the snows of Central Asia, another not less arduous devotee of science has been risking his life in the tropical forests of Madagascar, and has likewise made many brilliant discoveries. M. Alfred Grandidier, who has now returned from, we believe, his third voyage of discovery in that strange island, has shown that the riches and eccentricities of its fauna have not yet been exhausted. His collections, which have only reached the Jardin des Plantes very recently, although brought to France before the political storm of last autumn commenced, have not yet becn fully examined. But they are said to contain very full series of several species of Lemurida, the comparison of which is likely to lead to important results, besides examples of a new genus of Rodentia, and many other Mammals of high interest. M. Grandidier has also paid much attention to the fossil deposits of Southern Madagascar, which contain the remains of the extinct gigantic bird, AEpyornis maxima, and has arrived at some important results (such as the former presence of Hippopotamus in Madagascar) which may ultimately tend to modify some of the views generally held concerning the true nature of the fauna of this island and its origin.
P. L. S, 